KRYSTAL G. WALTMAN $(*)$ - CHARLES H. RAY JR. $(*)$ - MICHAEL L. WILLIAMS $(*)\left(^{\circ}\right)$

\title{
THE ARMORED SCALE INSECTS (HEMIPTERA DIASPIDIDAE) OF ALABAMA, USA $\left({ }^{1}\right)$
}

\author{
(*) Department of Entomology and Plant Pathology, Auburn University, Alabama, 36849, USA \\ $\left({ }^{\circ}\right)$ Corresponding author: Michael L. Williams, e-mail: willim9@auburn.edu \\ Waltman K.G., Ray C.H. Jr., Willıams M.L. - The armored scale insects (Hemiptera Diaspididae) of Alabama, USA. \\ A continuing survey of the armored scale insects of Alabama has resulted in recording 113 species in 47 genera \\ among the tribes Aspidiotini, Diaspidini, and Odonaspidini. Alabama now ranks second among states in the southeastern \\ United States in number of species of armored scales, trailing only Florida with its $150+$ species. Comments on some of the \\ more notable diaspidids, not previously collected in Alabama, are made along with notes on their hosts and distribution in \\ the State.
}

KeY WorDs: biodiversity, Aspidiotini, Diaspidini, Odonaspidini

\section{INTRODUCTION}

The family Diaspididae (armored scale insects), is a large and diverse family, which is widely distributed across the state of Alabama. Yet, there is no published literature available cataloging the occurrence of armored scale insects in Alabama. OWEN (1925), BoYd (1932), TipPins (1953), and WaLtman (2008) all did Master's theses pertaining to scale insects in general, or select scale insects that included Diaspididae in Alabama. WALTMAN (2008) was the most inclusive of the four and she listed 107 species in 42 genera as occurring in Alabama. Two studies on the biology of tea scale and obscure scale were completed by Chiu (1974) and Hendricks \& Williams (1992) respectively.

Although there is a lack of published information for Alabama distributions and records, work with this family in several other sister-states has been published. Comprehensive coverage of host plant relationships, distribution, and morphology was recorded for the armored scales of Florida by DekLE (1965). In Georgia, Beshear, Tippins, and Howell published a short listing in 1973, in which they cited 100 species in 46 genera (BESHEAR et al., 1973). There are also publications available for Mississippi \& Louisiana including HERRICK (1911) listing certain scale insects in the Mississippi region and HOWARD \& OLIVER (1985) listing the armored scales of Louisiana.

The purpose of this paper is to document the current results of a continuing survey on the scale insects of Alabama, begun in 1973, by publishing a listing of the species of armored scale insects recorded in Alabama to date.

\section{MATERIALS AND METHODS}

Upon joining the faculty at Auburn University in March of 1973, the third author began a research project to survey the scale insects of Alabama.

\footnotetext{
${ }^{1}$ Original scientific contribution presented and discussed at XIV International Symposium on Scale Insect Studies, Catania-Italy, 13-16 June 2016.
}

All the known literature pertaining to the family Diaspididae and its occurrence in Alabama was reviewed and any pertinent information was integrated into a research database. Literature on Diaspididae from surrounding states was also reviewed for comparison purposes. All generic and species names recorded from Alabama during this survey were compared to the diaspidid information listed on the scale insect database ScaleNet (http://scalenet.info) (GARCIA et. al. 2015) to insure that all of the records being generated used the most current terminology.

The slide collection and records of the U. S. National Museum and the U. S. Department of Agriculture in Beltsville, Maryland were examined for Alabama records and all information pertaining to Alabama records were incorporated in our survey database

Dried pre-collected material was gathered from around the state from different institutions and individuals to identify any species not already recorded in the state. They were then slide mounted, examined, identified, and pertinent collection information was recorded in the Auburn University scale card catalogue.

Throughout the survey fresh material was collected from different regions of Alabama. Special attempts were made to collect armored scales that had been recorded from neighboring states but had not yet been collected in Alabama. Samples of all collected material were slide mounted, assigned a slide number, identified, and the slide number and collection information including host, locality, date of collection and collector were recorded in both a slide mounting record book and a survey database. All slide-mounted specimens collected during the survey are deposited in the Auburn University Coccoidea Collection (AUCC).

Additional information was recorded for each identified species that included: biology, distribution across Alabama, a listing of host plant species, a photograph of the specimens (before slide mounting), and a short description of morphological characters of the cover, for aid in simplification of field identification. This information will be used to publish a manual of the Diaspididae of Alabama for use by extension personnel, regulatory officials, and the general public at a later date. 


\section{RESULTS AND DISCUSSION}

Prior to this survey, begun in 1973 , only 48 species belonging to 17 genera of Diaspididae were recorded in Alabama. As a result of this survey, Alabama now has recorded 113 species in 47 genera. A breakdown of the armored scale insects of Alabama listed by tribe, genus, and number of species (in parentheses) is presented in Table 1, and an alphabetical listing of the 113 species currently recorded in Alabama is presented in Table 2. This study has added 65 previously unrecorded species of Diaspididae in Alabama. Not included in the list of species recorded in Alabama are an undescribed species of Clavaspis and an undescribed species of Lindingaspis which were collected in Alabama and are currently being described.

Table 1 - Alabama armored scale insects.

(Reported by tribe, genera, and number of species in parentheses)

\begin{tabular}{|c|c|}
\hline Odonaspidini - 2 genera & Diaspidini - 24 genera \\
\hline Odonaspis (3) & Aonidomytilus (4) \\
\hline \multirow[t]{2}{*}{ Froggattiella (1) } & Aulacaspis (2) \\
\hline & Carulaspis (2) \\
\hline Aspidiotini - 21 genera & Chionaspis (13) \\
\hline Abgrallaspis (3) & Diaspis (4) \\
\hline Acutaspis (2) & Duplachionaspis (1) \\
\hline Aonidia (1) & Fiorinia (2) \\
\hline Aonidiella (2) & Fissuraspis (1) \\
\hline Aspidiella (1) & Gymnaspis (1) \\
\hline Aspidiotus (3) & Haliaspis (1) \\
\hline Chortinaspis (1) & Kuwanaspis (3) \\
\hline Chrysomphalus (4) & Lepidosaphes (7) \\
\hline Clavaspis $(2+1$ undescribed $))$ & Lopholeucaspis (1) \\
\hline Comstockaspis (1) & Neopinnaspis (1) \\
\hline Comstockiella (1) & Niveaspis (1) \\
\hline Diaspidiotus (11) & Parlatoria (3) \\
\hline Dynaspidiotus (1) & Pinnaspis (2) \\
\hline Hemiberlesia $(5)$ & Pseudaulacaspis (3) \\
\hline Lindingaspis (1 undescribed) & Pseudoparlatoria (1) \\
\hline Melanaspis (7) & Quernaspis (1) \\
\hline Morganella (1) & Thysanofiorinia (1) \\
\hline Oceanaspidiotus (1) & Unachionaspis (1) \\
\hline Pseudaonidia (2) & Unaspis (1) \\
\hline Rhizaspidiotus (1) & Velataspis (1) \\
\hline Selenaspidus (1) & \\
\hline
\end{tabular}

The following two species, previously recorded in Alabama, could not be verified by us as actually occurring in the State as they were not recollected by us and there were no slide-mounted specimens from Alabama in any of the collections we examined: Chrysomphalus diversicolor (Green) - A single USDA record listed this species as being collected from Jefferson County, Alabama on palms. The Birmingham Botanical Gardens is in Jefferson County and they have a palm collection so this is possibly a valid record; and Lepidosaphes lasianthi (Green) - Another USDA record listed this species as occurring in Alabama, but according to TAKAGI (1970) all records of Lepidosaphes lasianthi in Hawaii, the Philippines and North America are all misidentifications of Lepidosaphes tokionis (Kuwana). We have not collected L. tokionis in Alabama and the listing of this species in Table 2 is based on the reference by TAKAGI (1970).

Alabama now ranks number two in terms of number of species of diaspidids in the southeastern United States. Alabama is second only to Florida with $150+$ species. The only other state in our region that has recorded anywhere near as many species as Alabama is our neighboring state of Georgia with 105 diaspidids recorded. Although our other neighbors like Mississippi, Tennessee, Louisiana and Kentucky have recorded much lower numbers of species (all below 70), we have no doubt that this is largely due to a lack of collecting with this particular group of insects in those states.

Some of the more notable diaspidids that were not previously collected in Alabama include Melanaspis arundinariae Deitz \& Davidson, which had previously only been collected in South Carolina as far as U.S. records are concerned. They also include Quernaspis quercicola Tippins \& Beshear, which worldwide had only been collected in Georgia and is quite a rare find. Lastly, Diaspidiotus crystallinus Ferris has also been found in Alabama in multiple locations and had only been recorded worldwide from Texas.

The discovery of these and several other newly recorded diaspidids have great implications for Alabama and the surrounding states. Species that were previously thought to be primarily of western distribution, like $D$. crystallinus and Clavaspis texana Ferris, may actually be distributed across the nation. Species that are considered serious pests in other states, like the newly recorded Aspidiella sacchari (Cockerell), may be newly introduced or may simply be inhibited by some unseen factor keeping it from reaching pest status in Alabama. More research and additional surveys in other states would greatly contribute to helping answer these questions and many more for the better of state-wide integrated pest management programs.

\section{ACKNOWLEDGEMENTS}

The third author thanks all his former graduate students who spent many hours collecting and mounting scale insects during the many years of this survey, but especially Krystal Waltman, Charles H. Ray, Jr., Gary L. Miller, Harlan Hendricks and Takumasa (Demian) Kondo.

Thanks to Dr. Dug Miller (retired) and Dr. Gary L. Miller, Systematic Entomology Laboratory, USNM Coccoidea Collection, Beltsville, Maryland, for allowing us access to the collection and associated records of the USNM.

\section{REFERENCES}

Beshear R.J., Tippins H.H., Howell J.O., 1973 - The armored scale insects (Homoptera: Diaspididae) of Georgia and their hosts. - University of Georgia, College of Agriculture Experiment Station. Bulletin 146. 15 pp.

BoyD C.P., 1932 - A partial list of the scale insects of Lee County, Alabama. M.S. Thesis, Alabama Polytechnic Institute, Auburn, Alabama, 42 pp.

CHIU C.H., 1974 - Biological studies on tea scale Fiorinia theae Green (Homoptera: Diaspididae). M.S. Thesis, Auburn University, Auburn, Alabama. 76 pp.

DEKLE G.W., 1965 - Florida armored scale insects. Arthropods of Florida and Neighboring Land Areas, Vol $3.342 \mathrm{pp}$.

Garcia M., Denno B., Miller D.R., Miller G.L., BenDov Y., Hardy N.B., 2015 - ScaleNet: A Literaturebased model of scale insect biology and systematics. http://scalenet.info (Last accessed 8/15/2016).

HenDRICKS H.J., WiLliams M.L., 1992 - Life history of Melanaspis obscura (Homoptera: Diaspididae) infesting pin oak in Alabama. - Annals of the Entomological Society of America, 85(4): 452-457. 
Table 2 -Alphabetical listing of the Diaspididae recorded in Alabama.

\begin{tabular}{|c|c|}
\hline 1. Abgrallaspis cyanophylli (Signoret) & 58. Duplachionaspis divergens (Green) \\
\hline 2. Abgrallaspis ithacae (Ferris) & 59. Dynaspidiotus californicus (Coleman) \\
\hline 3. Abgrallaspis liriodendri Miller and Howard & 60. Fiorinia fioriniae (Targioni-Tozzeti) \\
\hline 4. Acutaspis morrisonorum Kosztarab & 61. Fiorinia theae Green \\
\hline 5. Acutaspis perseae (Comstock) & 62. Fissuraspis ulmi (Hoke) \\
\hline 6. Aonidia atlantica Ferris & 63. Froggattiella penicillata (Green) \\
\hline 7. Aonidiella aurantii (Maskell) & 64. Gymnaspis aechmeae Newstead \\
\hline 8. Aonidiella taxus Leonardi & 65. Haliaspis spartinae (Comstock) \\
\hline 9. Aonidomytilus crookiae (Ferris) & 66. Hemiberlesia diffinis (Newstead) \\
\hline 10. Aonidomytilus hyperici Ferris & 67. Hemiberlesia lataniae (Signoret) \\
\hline 11. Aonidomytilus sabatius Tippins & 68. Hemiberlesia neodiffinis Miller \& Davidson \\
\hline 12. Aonidomytilus solidaginis (Hoke) & 69. Hemiberlesia palmae (Cockerell) \\
\hline 13. Aspidiella sacchari (Cockerell) & 70. Hemiberlesia rapax (Comstock) \\
\hline 14. Aspidiotus cryptomeriae Kuwana & 71. Kuwanaspis hikosani (Kuwana) \\
\hline 15. Aspidiotus marisci Tippins \& Beshear & 72. Kuwanaspis howardi (Cooley) \\
\hline 16. Aspidiotus nerii Bouché & 73. Kuwanaspis pseudoleucaspis (Kuwana) \\
\hline 17. Aulacaspis rosae (Bouché) & 74. Lepidosaphes beckii (Newman) \\
\hline 18. Aulacaspis yasumatsui Takagi & 75. Lepidosaphes camelliae Hoke \\
\hline 19. Carulaspis juniperi (Bouché) & 76. Lepidosaphes gloverii (Packard) \\
\hline 20. Carulaspis minima (Signoret) & 77. Lepidosaphes lasianthi (Green) \\
\hline 21. Chionaspis americana Johnson & 78. Lepidosaphes newsteadi (Sulc) \\
\hline 22. Chionaspis caryae (Cooley) & 79. Lepidosaphes pallida (Maskell) \\
\hline 23. Chionaspis furfura (Fitch) & 80. Lepidosaphes ulmi (Linnaeus) \\
\hline 24. Chionaspis gleditsiae Sanders & 81. Lopholeucaspis japonica (Cockerell) \\
\hline 25. Chionaspis heterophyllae Cooley & 82. Melanaspis arundinariae Deitz \& Davidson \\
\hline 26. Chionaspis kosztarabi Takagi \& Kuwana & 83. Melanaspis bromeliae (Leonardi) \\
\hline 27. Chionaspis longiloba Cooley & 84. Melanaspis deklei Dietz \& Davidson \\
\hline 28. Chionaspis nyssae Comstock & 85. Melanaspis nigropunctata (Cockerell) \\
\hline 29. Chionaspis pinifoliae (Fitch) & 86. Melanaspis obscura (Comstock) \\
\hline 30. Chionaspis platani (Cooley) & 87. Melanaspis smilacis (Comstock) \\
\hline 31. Chionaspis salicis (Linnaeus) & 88. Melanaspis tenebricosa (Comstock) \\
\hline 32. Chionaspis styracis Liu \& Kosztarab & 89. Morganella cueroensis (Cockerell) \\
\hline 33. Chionaspis triformis Tippins \& Beshear & 90. Neopinnaspis harperi McKenzie \\
\hline 34. Chortinaspis subchortina (Laing) & 91. Niveaspis ilicis (Hoke) \\
\hline 35. Chrysomphalus aonidum (Linnaeus) & 92. Oceanaspidiotus spinosus (Comstock) \\
\hline 36. Chrysomphalus bifasciculatus Ferris & 93. Odonaspis benardi Balachowsky \\
\hline 37. Chrysomphalus dictyospermi (Morgan) & 94. Odonaspis ruthae Kotinsky \\
\hline 38. Chrysomphalus diversicolor (Green) & 95. Odonaspis saccharicaulis (Zehntner) \\
\hline 39. Clavaspis crypta Howell \& Tippins & 96 Parlatoria camelliae Comstock \\
\hline 40. Clavaspis texana Ferris & 97. Parlatoria pergandii Comstock \\
\hline 41. Comstockaspis perniciosis (Comstock) & 98. Parlatoria theae (Cockerell) \\
\hline 42. Comstockiella sabalis (Comstock) & 99. Pinnaspis aspidistrae (Signoret) \\
\hline 43. Diaspidiotus ancylus (Putnam) & 100. Pinnaspis strachani (Cooley) \\
\hline 44. Diaspidiotus bumeliae Ferris & 101. Pseudaonidia duplex (Cockerell) \\
\hline 45. Diaspidiotus coniferarum (Cockerell) & 102. Pseudaonidia paeoniae (Cockerell) \\
\hline 46. Diaspidiotus crystallinus Ferris & 103. Pseudaulacaspis cockerelli (Cooley) \\
\hline 47. Diaspidiotus forbesi (Johnson) & 104. Pseudaulacaspis pentagona (Targioni-Tozzetti) \\
\hline 48. Diaspidiotus juglansregiae (Comstock) & 105. Pseudaulacaspis prunicola (Maskell) \\
\hline 49. Diaspidiotus liquidambaris (Kotinsky) & 106. Pseudoparlatoria parlatorioides (Comstock) \\
\hline 50. Diaspidiotus mccombi McKenzie & 107. Quernaspis quercicola Tippins \& Beshear \\
\hline 51. Diaspidiotus osborni (Newell \& Cockerell) & 108. Rhizaspidiotus dearnessi (Cockerell) \\
\hline 52. Diaspidiotus taxodii (Ferris) & 109. Selenaspidis articulatus (Morgan) \\
\hline 53. Diaspidiotus uvae (Comstock) & 110. Thysanofiorinia nephelii (Maskell) \\
\hline 54. Diaspis boisduvalii Signoret & 111. Unachionaspis tenuis (Maskell) \\
\hline 55. Diaspis bromeliae (Kerner) & 112. Unaspis euonymi (Comstock) \\
\hline 56. Diaspis echinocacti (Bouché) & 113. Veletaspis dentata (Hoke) \\
\hline
\end{tabular}

57. Diaspis townsendi Cockerell

HERRICK G.W., 1911 - Some scale insects of Mississippi with notes on certain species from Texas. - Mississippi Agricultural Experiment Station Technical Bulletin 2: 178.

Howard F.W., Oliver A.D., 1985 - Armored scale insects (Homoptera: Diaspididae) of Louisiana. - Bulletin of the Louisiana Experiment Station 767: 1-125.

OwEN W.L., 1925 - A preliminary list of the scale insects of Alabama. M.S. Thesis, Alabama Polytechnic Institute, Auburn, Alabama. 46 pp.

TAKAGi S., 1970 - Diaspididae of Taiwan based on

material collected in connection with The Japan-U.S. Cooperative Science Programme. 1965 (Homoptera:Coccoidea). Pt. II. - Insecta Matsumurana, 33: 1-146.

TIPPINS H.H., 1953 - The scale insects of Alabama. M.S. Thesis, Alabama Polytechnic Institute, Auburn, Alabama. $70 \mathrm{pp}$.

WALTMAN K.G., 2008 - The armored scale insects of Alabama (Hemiptera: Diaspididae). M.S. Thesis, Auburn University, Auburn, Alabama. 177 pp. 
